\title{
IL15 Antibody
}

National Cancer Institute

\section{Source}

National Cancer Institute. IL15 Antibody. NCI Thesaurus. Code C129680.

Any immunog lobulin that recognizes interleukin-15 protein. 